\title{
ELECTRIC SIGNALS AS A TOOL FOR SEPARATION OF EARTHWORMS (Eisenia foetida) FROM HUMUS
}

\author{
Maria Joselma de Moraes ${ }^{1}$, Delly Oliveira Filho², José Helvécio Martins ${ }^{3}$, Luiz Carlos dos Santos ${ }^{4}$
}

\begin{abstract}
Improving the efficiency of the earthworms separation process from its substrate (humus) is important because this is the most labor and time intensive stage. In this study the same techniques used in electrical fishing was employed with some adaptations for earthworm separation. Therefore, the effect of an electric field produced by controlled electric signals was studied for displacement of the earthworm Eisenia foetida. The study was conducted at the Energy in Agriculture Laboratory of the Department of Agricultural Engineering, Federal University of Viçosa, MG. The earthworms preferentially moved towards one of the electrodes, as observed in more than $90 \%$ of the cases. Therefore, based on these results, it could be concluded that utilization of controlled electrical signals is technically suitable for separation of earthworms from humus.
\end{abstract}

Keywords: Vermiculture, vermicomposting, electricity pulsing, earthworms.

\section{RESUMO}

\section{SINAIS ELÉTRICOS COMO FERRAMENTA PARA SEPARAÇÃO DE MINHOCAS (EISENIA FOETIDA) DO HÚMUS}

Melhorar eficiência do processo de separação de minhocas do húmus é importante porque este é o estágio que requer mais mão-de-obra e também exige mais tempo. Neste trabalho, as mesmas técnicas usadas na pesca elétrica foram utilizadas com adaptações para a separação de minhocas. Assim, avaliou-se o efeito de um campo elétrico, produzido por sinais elétricos controlados, no deslocamento de minhocas Eisenia fœetida. O estudo foi realizado no Laboratório de Energia na Agricultura do Departamento de Engenharia Agrícola da Universidade Federal de Viçosa, Viçosa, MG. As minhocas se deslocaram preferencialmente para o anodo, em mais de $90 \%$ das observações. A partir dos resultados obtidos, pode-se afirmar que a utilização de pulsos elétricos controlados é viável tecnicamente para separação de minhocas do húmus.

Palavras-Chave: Vermicultura, vermicompostagem, e eletricidade na minhocultura.

\section{Recebido para publicação em 01/02/2013. Aprovado em 30/07/2013.}

1 MSc, Agricultural Eng. State University of Goias, UnUCET, Anapolis, Goias, Brazil, E-mail: mjoselma.moraes@ueg.br $2 \mathrm{PhD}$, Agricultural Eng. Dept. Federal University of Viçosa, Viçosa, MG, Brazil. E-mail: delly@ufv.br;

3 PhD, Agricultural Eng. Dept. Federal University of Viçosa, Viçosa, MG, Brazil. E-mail: jhmartins@ufv.br 4 PhD, Animal Biology Dept. Federal University of Vicosa, Viçosa, MG, Brazil. E-mail: 1csantos@ufv.br 


\section{INTRODUCTION}

Earthworms play an important role in the terrestrial ecosystem because they modify chemical, physical and microbiological properties of the soil. They are very important with regards to pedogenetical aspects to decompose organic material (ARANCON et al., 2006; JOHNSONMAYNARD et al., 2007). They also contribute to increase water infiltration rates in the soil, stability of aggregates and macroporosity of the soil (BLANCHART et al., 2004).

Since the 1940's, production of earthworms has been developed and considerably improved in countries such as the United States and England. They are mainly utilized for solid wastes management, commercialization as bait, production of animal feeds, fertilization and detoxification of soils, and production of vermicompost (SINHA et al., 2002).

Vermicomposting is the process of decomposing organic material by the joint action of worms and microorganisms. It is a natural, profitable and fast process, taking one to two weeks for completion (ADI ; NOOR, 2009). While bacteria biochemically degraded the organic matter, worms control the process, conditioning the substrate and modifying its biological activity (SUTHAR, 2009).

The final product, denominated vermicompost, is a very good organic fertilizer and provides greater vegetal growth, contributing to increase productivity (ATIYEH et al., 2002). Moreover, because vermicompost presents desired aesthetics characteristics and low contaminant concentrations, its commercialization is favored (NDEGWA; THOMPSON, 2001).

Vermicomposting is an excellent alternative to reduce environmental impacts, since it permits bioaccumulation of heavy metals and contribute to reduce waste volume. Therefore, vermicomposting plays an important role in the treatment of pollutants and moreover diminishing public health problems (STEFFEN et al., 2006). Among the species of earthworms utilized in the vermicomposting process, Eudrilus eugenice (African night crawler) and Eisenia foetida (California red worm) are commonly used. The first is largely employed in vermiculture processes because it grows and reproduces rapidly (DOMINGUEZ et al., 2001). The second is widely used in vermicomposting when large amounts of organic material need to be processed per day. In order to acquire the worms for further use they must be separated them from the substrate, called humus. The process of separating worms from humus is an operation that requires great care and is very time consuming. If the efficiency of this process were improved it could significantly contribute to increase the economic viability of vermiculture and/or vermicomposting.

Selection of the separation method basically depends on the final destination of the worm, which can be for a small sample or commercialization. The methods normally used are (i) manual, (ii) mechanical, and (iii) behavioral.

Manual methods are labor intensive and their applications are limited to small samples (COJA et al., 2008). On the other hand, in mechanical method worms are separated using sieves and/or vibrators, which can cause injuries to the worms during the extraction operation, therefore complicating the distinction between live and dead worms (BOUMA et al., 2001).

Behavioral or dynamic methods are those that cause the animals to leave the substrate due to the influence of stimulants, such as attraction to food, heat, electrical shocks, inundation or chemical repellents (BOUMA et al., 2001).

Rushton and Luff (1984) used an alternating current to evaluate the separation of worms from soil substrates. They used two electrodes, one in the center of the sample and the other forming a ring, surrounding the soil volume to create an electric field. The electrodes were connected to a transformer with output voltage ranging from 1 to $240 \mathrm{~V}$, and current varying between 1 and 10 A. Their result demonstrated that the worms were repelled by the action of the electric field, and the method was more efficient for young individuals.

In another study a different separation method was used compared to normal practices, which is the use of controlled electric pulses. The pulses are similars to those used in electrical fishing. In the case of electrical fishing it is possible to control the species and animal size, and is a function of electrical conductivity of the water and the 
geometry of the animal body. So in theory it may be considered a selective (fishing) activity according to species and size (MAZZONI et al., 2000).

Since the substrate used for earthworms growth is humus with high water content, this same principle could be adapted for separation of earthworms, in which the space between the electrodes is filled with the substrate containing the earthworms.

Other experiments using electricity have also been performed for evaluating the movement of different animals, including the use of aquatic electric nets, which repel mammals without causing injury and projected walls for repulsion of badgers using different voltage and current levels (CHAOUI; KEENER, 2008). Due to the effect of electric fields on these animals, these authors developed a mathematical model which characterizes the efficacy of the electric field for repulsion of worms, and identify the factors which may affect the movement of these animals, including depth and space between the electrodes, current level, and worm species. According to these same authors, none of the previous studies investigated the use of controlled electrical pulses to separate worms from the substrate, but only investigated the use of a sinusoidal or constant electrical signal to stimulate the worms in order to separate them from the substrate. Such experiments indicated that the use of sinusoidal or direct current signals were of little efficiency in the worm separation process
(RUSHTON; LUFF, 1984).

The objective of the present study was to verify and validate the utilization of controlled electrical pulses to efficiently separate Eisenia foetida (California red worm) earthworms from bovine manure humus.

\section{MATERIALS AND METHODS}

The experiment was performed at the Department of Agricultural Engineering, Federal University of Viçosa, Viçosa, Minas Gerais, Brazil, in the year 1998. In order to determine the efficiency of controlled electrical pulses on the separation of earthworms from humus, a portable pulse generator designed for electrical fishing was used with some adaptations. The specie used in the experiments, Eisenia foetida (California red worm), is largely employed in vermiculture processes because it grows and reproduces rapidly (DOMINGUEZ et al., 2001).

The experimental apparatus was composed of a glass box with wall thickness of $4 \mathrm{~mm}$ and dimensions of $500 \times 500 \times 200 \mathrm{~mm}$; a pulse generator; two aluminum electrodes with thickness of $1 \mathrm{~mm}$, length of $500 \mathrm{~mm}$ and width of $30 \mathrm{~mm}$. Also, two glass plates with thickness of $4 \mathrm{~mm}$, length of $900 \mathrm{~mm}$, and width of $800 \mathrm{~mm}$ were place underneath the glass box to improve insulation. An schemati of this experimental setup is shown in Figure 1.

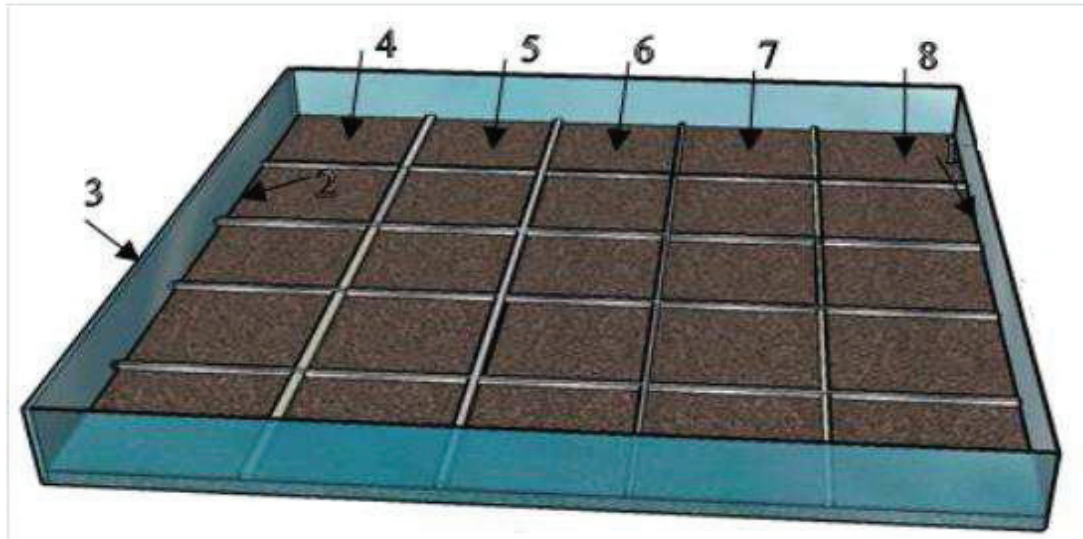

Legend:

1 - electrode cathode

2 - electrode anode

3 - test recipient

$4-1^{\text {st }}$ row

$5-2^{\text {nd }}$ row

$6-3^{\text {rd }}$ row

$7-4^{\text {th }}$ row

$8-5^{\text {th }}$ row

Figure 1. Experimental apparatus used in the tests 
The aluminum electrodes were placed at the two extremities of the test box. A layer of bovine manure vermicompost (humus) was placed between the electrodes with a thickness of $30 \mathrm{~mm}$. An accommodation square cell measuring $100 \mathrm{x}$ $100 \mathrm{~mm}$, with a wall thickness of $1 \mathrm{~mm}$ and height of $50 \mathrm{~mm}$, was placed at the center of the test box. Ten worms were placed inside this cell and worms were provided a five minute accommodation period (Figure 2). After this time, the accommodation cell was removed and the circuit activated, exposing the worms to the electrical signal for a period of 15 and 30 minutes, respectively.

The pulse generator supplied a variable time signal with the characteristics of a rapid vertical rise and gradual descent, as shown in Figure 3.

After the exposure period, the circuit was deactivated and a separation structure constructed of galvanized steel with a thickness of $1 \mathrm{~mm}$ was introduced in the test recipient. The separation structure measured $500 \times 500 \mathrm{~mm}$, and was divided into $100 \times 100 \mathrm{~mm}$ sections measuring with $50 \mathrm{~mm}$ in height. Therefore, a total of 25 square cells were created, consisting of 5 rows with 5 cells each that were in parallel to the electrodes, as shown in Figure 1. After exposure to the electrical signals, the position of each worm was determined in relation to the 25 separation cells, and the corresponding row, considering the accommodation cell (center of the box) as a reference.

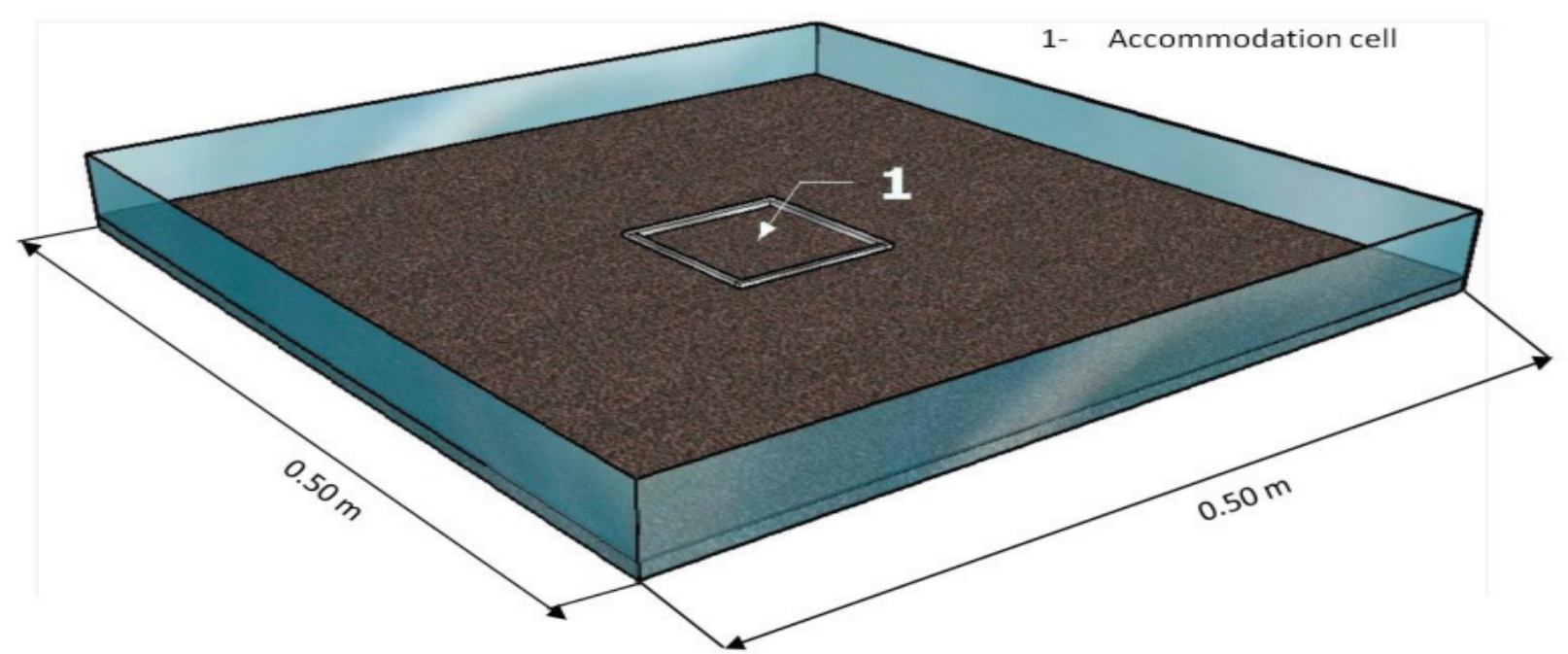

Figure 2. Experimental apparatus showing the accommodation cell

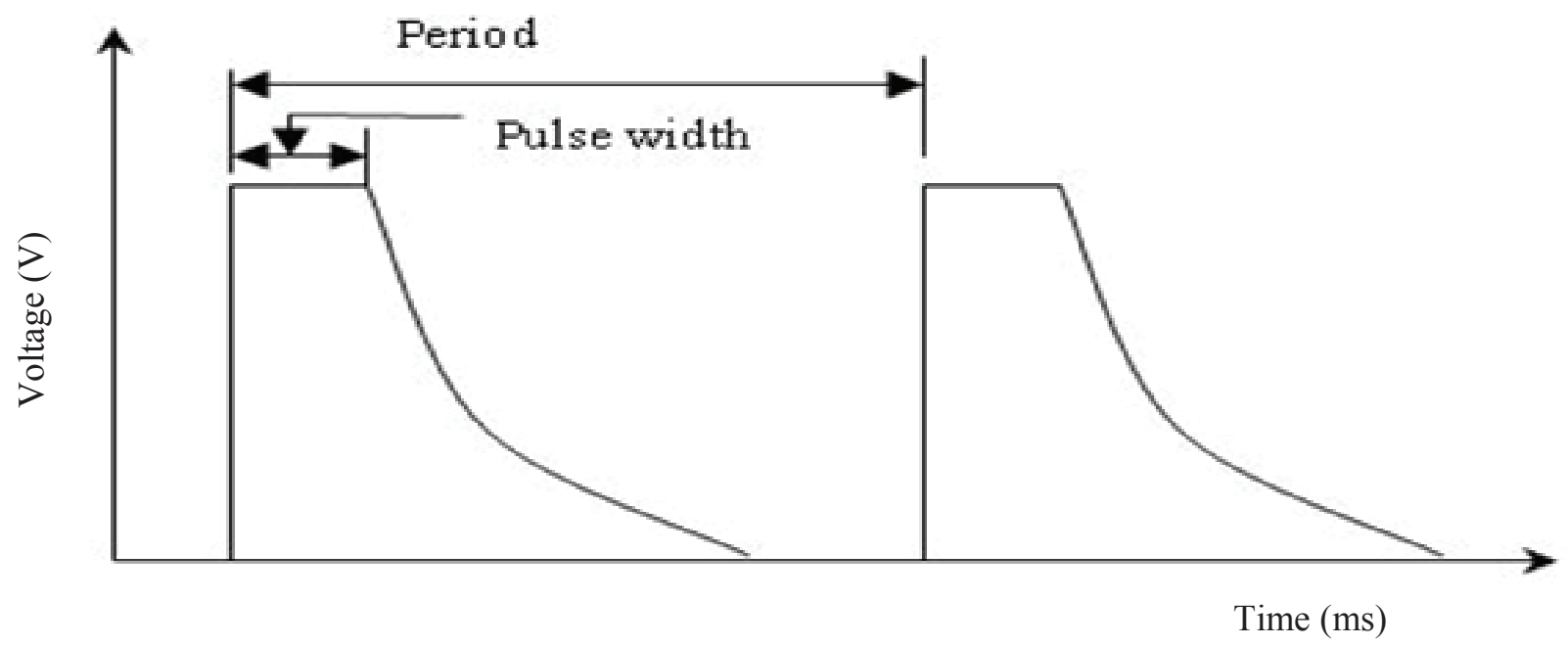

Figure 3. Wave form of the signal supplied by the pulse generator 
To determine the position of each worm in relation to the reference cell (the center cell), a parameter referred to as the displacement index was defined as follows (Equation 1).

$I_{d}=\sum_{n=1}^{p} \sum_{m=1}^{q} \frac{m(n-3)}{2}$

where,

$I_{d}=$ dislocation index

$\mathrm{p}=$ number of rows considered (5)

$q=$ number of worms in each of the 5 rows after the exposure time

$\mathrm{m}=$ number of worms encountered in each of the 5 rows of square cells

$\mathrm{n}=$ location of the worms in relation to the rows of square cells

Application of the equation 1 thus allows for determining the average earthworm displacement after being exposed to the electrical pulses. Prior to application of the electric pulses the 10 earthworms where placed in the middle of the recipient (Figure 2) and when in this position the value of $I_{d}$ is equals to zero. Supposing that after the tests all the earthworms moved to the first row in the direction of the anode, then the $I_{d}$ will be 5, indicating that they had moved up to $50 \%$ at the end (that is the last row).

The worms submitted to controlled electrical pulses were studied regarding their survival rate, because it is possible that electrical signals may have adverse effects on their health. At the end of each test, a random sample of 10 worms was taken and placed in a recipient containing bovine manure substrate (humus), with moisture content of approximately $70 \%$ (wet basis), where they remained for 15 days. During this period the survival rate was evaluated at 5 day intervals by counting. For each treatment the average survival percentage was calculated.

Results were statistically analyzed based on the factorial combination of three widths of electrical pulses (2, 3 and $4 \mathrm{~ms}$ ), two signal frequencies ( 1 and $5 \mathrm{~Hz}$ ), two exposure times (15 and 30 minutes) and two voltages (100 and 200 V). These combinations resulted in a $3 \times 2 \times 2 \times 2$ factorial scheme. The treatments were organized in a completely randomized scheme with four replications. The effects of the treatments were evaluated in relation to the displacement index using statistical analysis.

\section{RESULTS AND DISCUSSION}

It should first be emphasized that few papers have discussed the effect of controlled electrical pulses for earthworm separation with the type of signal used in the present study. However, it should be noted that previous studies have utilized other types of electrical signals such as sinusoidal current and direct current (CHAOUI; KEENER, 2008; RUSHTON; LUFF, 1984; COJA et al., 2008).

The sources of variation considered in the present study and their interactions are shown in Table 1. According to the analysis presented in Table 2, it can be observed that the interactions involving V, $\mathrm{PW}, \mathrm{f}$ and $\mathrm{T}$ were significant for the displacement index. Therefore it was necessary to study each factor, considering possible combinations between each of them and the remaining factors.

The results in Table 2 show that the main significant factors for the displacement index were $\mathrm{T}, \mathrm{V}$, and $\mathrm{f}$. The significant interactions were $\mathrm{T} x \mathrm{f}$, $\mathrm{V} x \mathrm{f}, \mathrm{T} x \mathrm{~V} x \mathrm{f}$ and $\mathrm{T} x \mathrm{PW} \mathrm{x}$ f. Although some of the factors had significant independent effects, this study focused on the interactions (Table 2). The analysis of variance applied to the displacement index of the experimental data considering all variables and their interactions presented in Table 1 is shown in Table 2.

The effect of exposure time (T) on the worm displacement index (Id) and on the contributions of pulse width, (PW in ms), voltage $(\mathrm{V})$ and frequency (f) were studied. The interactions between these variables for the two exposure periods (15 and 30 minutes) resulted in 12 combinations, as shown in Table 3.

According to Oliveira Filho et al. (2005), the exposure time was significant for the separation of Eudrilus engeniae earthworms from the substrate and the most efficient frequency was $1 \mathrm{~Hz}$. Chaoui and Keener (2008) also verified that the exposure time was significant for both DC and AC currents on the Eisenia foetida species. 
Table 1. Sources of variation and their interactions used in the data analysis

\begin{tabular}{|c|c|}
\hline Variable or Interaction & Description \\
\hline $\mathrm{T}$ & Exposure time to which the worms were subjected, min. \\
\hline $\mathrm{V}$ & Voltage applied to the worms, $\mathrm{V}$ \\
\hline $\mathrm{T} \times \mathrm{V}$ & Interaction between $\mathrm{T}$ and $\mathrm{V}$. \\
\hline PW & Pulse width, duration of the pulse, ms. \\
\hline Tx PW & Interaction between $\mathrm{T}$ and $\mathrm{PW}$. \\
\hline $\mathrm{V} \times \mathrm{PW}$ & Interaction between $\mathrm{V}$ and $\mathrm{PW}$. \\
\hline Tx V x PW & Interaction between $\mathrm{T}, \mathrm{V}$ and $\mathrm{PW}$. \\
\hline $\mathrm{f}$ & Frequency of the pulse applied to the worms, Hz. \\
\hline $\mathrm{Txf}$ & Interaction between $\mathrm{T}$ and $\mathrm{f}$. \\
\hline $\mathrm{Vxf}$ & Interaction between $\mathrm{V}$ and $\mathrm{f}$. \\
\hline $\mathrm{T} \times \mathrm{Vxf}$ & Interaction between $\mathrm{T}, \mathrm{V}$ and $\mathrm{f}$. \\
\hline PW x f & Interaction between $\mathrm{PW}$ and $\mathrm{f}$. \\
\hline Tx PW x f & Interaction between $\mathrm{T}, \mathrm{PW}$ and $\mathrm{f}$. \\
\hline$V \times P W x f$ & Interaction between $\mathrm{V}, \mathrm{PW}$ and $\mathrm{f}$. \\
\hline$T \times V \times P W x f$ & Interaction between $\mathrm{T}, \mathrm{V}, \mathrm{PW}$ and $\mathrm{f}$. \\
\hline
\end{tabular}

Table 2. Analysis of variance and interactions used in the data analysis

\begin{tabular}{|c|c|c|}
\hline Source of Variation & Degrees of Freedom & Mean Square \\
\hline $\mathrm{T}$ & 1 & $36.26 *$ \\
\hline V & 1 & 114.84 \\
\hline $\mathrm{T} \times \mathrm{V}$ & 1 & $0.000 \mathrm{r}$ \\
\hline PW & 2 & $1.9296 \mathrm{r}$ \\
\hline T x PW & 2 & $7.1971 *$ \\
\hline $\mathrm{V} \times \mathrm{PW}$ & 2 & $3.7578 \mathrm{r}$ \\
\hline Tx V x PW & 2 & $1.0078 \mathrm{r}$ \\
\hline $\mathrm{F}$ & 1 & 189.84 \\
\hline Txf & 1 & 20.166 * \\
\hline $\mathrm{Vxf}$ & 1 & 210.04 \\
\hline$T x V x f$ & 1 & 7.5937 \\
\hline $\mathrm{PW} x \mathrm{f}$ & 2 & $5.164 \mathrm{r}$ \\
\hline T x PW x f & 2 & 13.143 \\
\hline V x PW x f & 2 & $5.3151 \mathrm{r}$ \\
\hline Tx V x PW x f & 2 & 6.3984 \\
\hline Residual & 72 & 1.8263 \\
\hline
\end{tabular}

Note: * and ** are significant at $1 \%$ and $5 \%$ probability, respectively, and ns stands for non-significant. 
The results presented in Table 3 demonstrate that the combinations $\mathrm{C} 2, \mathrm{C} 6, \mathrm{C} 7, \mathrm{C} 9, \mathrm{C} 10, \mathrm{C} 11$ and $\mathrm{C} 12$ are statistically identical; therefore they do not significantly affect the displacement index during the exposure times of 15 and 30 minutes. However, for the remaining combinations, the displacement index presented statistically significant differences, independently of the exposure time.

It can be observed in Table 3 that from the 12 combinations established between $\mathrm{PW}, \mathrm{V}$ and $\mathrm{f}$, the combinations $\mathrm{C} 1, \mathrm{C} 2, \mathrm{C} 4, \mathrm{C} 5, \mathrm{C} 6, \mathrm{C} 8, \mathrm{C} 9$ and $\mathrm{C} 12$ presented an increasing effect with regards to exposure time. This means that when the exposure time increased, there was an increase in the displacement index. For the other combinations, this behavior was the opposite, meaning that increases in the exposure time reduced the displacement index.

The greatest displacement index was observed for combination $\mathrm{C} 5$ and the lowest for $\mathrm{C} 11$, both for an exposure time of 30 minutes. The negative value for combination $\mathrm{C} 11$ indicated that not only was the displacement index minimal, but that the worms migrated towards the cathode. It was also observed that the combinations utilizing a frequency of $5 \mathrm{~Hz}$ and voltage of $200 \mathrm{~V}$ resulted in lower displacement indices. In these cases, the influence of time and pulse width appeared to be minimal.
The effects of exposure time $(\mathrm{T})$ on the worm displacement index (Id) and on the contributions of pulse width (PW), voltage (V) and frequency (f) were studied. Interactions between these variables for the two levels of exposure time ( 15 and 30 minutes) resulted in 12 combinations, as shown in Table 3.

The effect of voltage (V) on the worm displacement index (Id) as combined with pulse width (PW), exposure time (T) and frequency (f), is presented in Table 4, resulting in eight combinations (C14, C15, C16, C17, C18, C22, C23 and C24). It can be observed that the effects represented by combinations $\mathrm{C} 14, \mathrm{C} 15, \mathrm{C} 16, \mathrm{C} 17, \mathrm{C} 18, \mathrm{C} 22, \mathrm{C} 23$ and $\mathrm{C} 24$ presented significant differences between the two voltage levels (100 and $200 \mathrm{~V})$. However, the effects represented by combinations C13, C19, $\mathrm{C} 20$ and $\mathrm{C} 21$ showed no statistically significant difference for the two voltage levels studied.

It can be verified in Table 4 that the displacement index for combination C14 increased significantly, as compared with other combinations. It can also be observed that an increase in the voltage also caused an increase in the displacement index. For all other conditions, the displacement index presented opposite behavior, meaning that an increase in voltage reduced the displacement index, where this behavior was also verified by Oliveira Filho et al. (2005) for $200 \mathrm{~V}$ and $5 \mathrm{~Hz}$.

Table 3. Combinations of interactions between each main factor and the remaining factors

\begin{tabular}{cccccc}
\hline \multirow{2}{*}{ Combinations } & PW & V & f & \multicolumn{2}{c}{$\mathrm{T}(\mathrm{min})$} \\
\cline { 5 - 6 } & $(\mathrm{ms})$ & $(\mathrm{V})$ & $(\mathrm{Hz})$ & 15 & 30 \\
\hline $\mathrm{C} 1$ & 2 & 100 & 1 & $3.62 \mathrm{a}$ & $8.25 \mathrm{~b}$ \\
$\mathrm{C} 2$ & 3 & 100 & 1 & $5.87 \mathrm{a}$ & $7.12 \mathrm{a}$ \\
$\mathrm{C} 3$ & 4 & 100 & 1 & $6.00 \mathrm{a}$ & $4.87 \mathrm{~b}$ \\
$\mathrm{C} 4$ & 2 & 200 & 1 & $3.62 \mathrm{a}$ & $7.37 \mathrm{~b}$ \\
$\mathrm{C} 5$ & 3 & 200 & 1 & $5.50 \mathrm{a}$ & $9.25 \mathrm{~b}$ \\
$\mathrm{C} 6$ & 4 & 200 & 1 & $7.00 \mathrm{a}$ & $7.62 \mathrm{a}$ \\
$\mathrm{C} 7$ & 2 & 100 & 5 & $6.25 \mathrm{a}$ & $5.87 \mathrm{a}$ \\
$\mathrm{C} 8$ & 3 & 100 & 5 & $5.37 \mathrm{a}$ & $7.87 \mathrm{~b}$ \\
$\mathrm{C} 9$ & 4 & 100 & 5 & $5.37 \mathrm{a}$ & $5.87 \mathrm{a}$ \\
$\mathrm{C} 10$ & 2 & 200 & 5 & $1.62 \mathrm{a}$ & $1.50 \mathrm{a}$ \\
$\mathrm{C} 11$ & 3 & 200 & 5 & $0.87 \mathrm{a}$ & $-0.12 \mathrm{a}$ \\
$\mathrm{C} 12$ & 4 & 200 & 5 & $0.75 \mathrm{a}$ & $1.12 \mathrm{a}$ \\
\hline
\end{tabular}


Table 4. Effect of voltage on the displacement index

\begin{tabular}{cccccc}
\hline \multirow{2}{*}{ Combinations } & PW & T & $\mathrm{f}$ & \multicolumn{2}{c}{$\mathrm{V}$ (volts) } \\
\cline { 5 - 6 } $\mathrm{C} 13$ & $(\mathrm{~ms})$ & $(\mathrm{min})$ & $(\mathrm{Hz})$ & 100 & 200 \\
\hline $\mathrm{C} 14$ & 2 & 30 & 1 & $8.25 \mathrm{a}$ & $7.37 \mathrm{a}$ \\
$\mathrm{C} 15$ & 3 & 30 & 1 & $7.12 \mathrm{a}$ & $9.25 \mathrm{~b}$ \\
$\mathrm{C} 16$ & 4 & 30 & 1 & $4.87 \mathrm{a}$ & $7.62 \mathrm{~b}$ \\
$\mathrm{C} 17$ & 2 & 30 & 5 & $5.87 \mathrm{a}$ & $1.50 \mathrm{~b}$ \\
$\mathrm{C} 18$ & 3 & 30 & 5 & $7.87 \mathrm{a}$ & $-0.12 \mathrm{~b}$ \\
$\mathrm{C} 19$ & 4 & 30 & 5 & $5.87 \mathrm{a}$ & $1.12 \mathrm{~b}$ \\
$\mathrm{C} 20$ & 2 & 15 & 1 & $3.62 \mathrm{a}$ & $3.62 \mathrm{a}$ \\
$\mathrm{C} 21$ & 3 & 15 & 1 & $5.87 \mathrm{a}$ & $5.50 \mathrm{a}$ \\
$\mathrm{C} 22$ & 4 & 15 & 1 & $6.00 \mathrm{a}$ & $7.00 \mathrm{a}$ \\
$\mathrm{C} 23$ & 2 & 15 & 5 & $6.20 \mathrm{a}$ & $1.62 \mathrm{~b}$ \\
$\mathrm{C} 24$ & 3 & 15 & 5 & $5.37 \mathrm{a}$ & $0.87 \mathrm{~b}$ \\
\hline
\end{tabular}

Note: Averages followed by the same letter in the lines, for each voltage, did not differ at $5 \%$ probability by the $\mathrm{F}$ test.

Table 5. Effect of frequency on the displacement index

\begin{tabular}{|c|c|c|c|c|c|}
\hline \multirow{2}{*}{ Combinations } & \multirow{2}{*}{$\begin{array}{l}\text { PW } \\
(\mathrm{ms})\end{array}$} & \multirow{2}{*}{$\begin{array}{c}\mathrm{V} \\
(\mathrm{V})\end{array}$} & \multirow{2}{*}{$\begin{array}{c}\mathrm{T} \\
(\min )\end{array}$} & \multicolumn{2}{|c|}{$\mathrm{f}(\mathrm{Hz})$} \\
\hline & & & & 1 & 5 \\
\hline $\mathrm{C} 25$ & 2 & 100 & 15 & $3.62 \mathrm{a}$ & $6.25 b$ \\
\hline $\mathrm{C} 26$ & 3 & 100 & 15 & $5.87 \mathrm{a}$ & $5.37 \mathrm{a}$ \\
\hline $\mathrm{C} 27$ & 4 & 100 & 15 & $6.00 \mathrm{a}$ & $5.37 \mathrm{a}$ \\
\hline $\mathrm{C} 28$ & 2 & 200 & 15 & $3.62 \mathrm{a}$ & $1.62 \mathrm{~b}$ \\
\hline $\mathrm{C} 29$ & 3 & 200 & 15 & $5.50 \mathrm{a}$ & $0.87 b$ \\
\hline $\mathrm{C} 30$ & 4 & 200 & 15 & $7.00 \mathrm{a}$ & $0.75 b$ \\
\hline $\mathrm{C} 31$ & 2 & 100 & 30 & $8.25 \mathrm{a}$ & $5.87 \mathrm{~b}$ \\
\hline $\mathrm{C} 32$ & 3 & 100 & 30 & $7.12 \mathrm{a}$ & $7.87 \mathrm{a}$ \\
\hline $\mathrm{C} 33$ & 4 & 100 & 30 & $4.87 \mathrm{a}$ & $5.87 \mathrm{a}$ \\
\hline $\mathrm{C} 34$ & 2 & 200 & 30 & $7.37 \mathrm{a}$ & $1.50 \mathrm{~b}$ \\
\hline $\mathrm{C} 35$ & 3 & 200 & 30 & $9.25 \mathrm{a}$ & $1.12 b$ \\
\hline $\mathrm{C} 36$ & 4 & 200 & 30 & $7.62 \mathrm{a}$ & $1.12 \mathrm{~b}$ \\
\hline
\end{tabular}

Note: The averages followed by the same letter in the lines, for each frequency, did not differ at $5 \%$ probability by the F test. 
Table 5 presents the effect of frequency (f) on the displacement index (Id) for each combination of pulse width (PW), voltage (V) and exposure time (T). It can be verified that for the combinations $\mathrm{C} 25, \mathrm{C} 32$ and $\mathrm{C} 33$, the displacement index increased with an increase in the frequency from 1 to $5 \mathrm{~Hz}$. However, this increase was significant only for the combination C25. For the other combinations the increase in frequency reduced the displacement index. This reduction was significant for combinations C28, C29, C30, C31, C34, C35 and C36. Oliveira Filho et al. (2004) verified that the most expressive response was observed for a frequency of $1 \mathrm{~Hz}$, however at $5 \mathrm{~Hz}$ the results were not expressive due to the fact that the voltage caused stress to the animals.

Table 6 presents the effect of pulse width (PW) on the displacement index (Id) for each combination of exposure time $(\mathrm{T})$, voltage $(\mathrm{V})$ and frequency (f).

The results in Table 6 show that for the combinations C37 and C39, the displacement index increased significantly as the pulse width increased. For the combinations C40 and C41, the behavior of the displacement index was the opposite, meaning that an increase in the pulse width reduced the displacement index, although this reduction was significant only for the last combination (C44).

The higher values of the displacement index occurred in the combinations $\mathrm{C} 42$ and $\mathrm{C} 43$ for the pulse width of $3 \mathrm{~ms}$, with smaller values for 2 and $4 \mathrm{~ms}$, however with no significant difference on the displacement indices. The displacement index for combination $\mathrm{C} 38$ decreased for the pulse width of $3 \mathrm{~ms}$, but remained constant at $4 \mathrm{~ms}$, meaning that this decrease is non-significant.

The survival rates for the species Eisenia feetida after 5, 10 and 15 days of exposure to the electrical field, as a function of each tested combination and moisture content of the substrate, are shown in Table 7.

It was observed that for the majority of the combinations, all worms exposed to the electrical signal were alive after 15 days. Exceptions were observed for the combinations involving frequency of $5 \mathrm{~Hz}$ and voltage of $200 \mathrm{~V}$, in which 2 to $10 \%$ of the worms were found dead in the first 5 days after exposure to the electrical signal. Similar values was observed by Oliveira Filho (2005), were the Eudrillus Eugeniae earthworm survival rate after being exposed to the electric field was $100 \%$ and approximately $96.5 \%$ for 1 and $5 \mathrm{~Hz}$, respectively.

The earthworms present behavior similar to fish in response to the electrical pulses. Electrical fishing utilizes frequencies of roughly $120 \mathrm{~Hz}$ to capture small fish, while for the separation of earthworms from humus the best results were found to be at relatively low frequency $(1 \mathrm{~Hz})$.

Table 6. Effect of pulse width on the displacement index

\begin{tabular}{|c|c|c|c|c|c|c|}
\hline \multirow{2}{*}{ Combinations } & \multirow{2}{*}{$\begin{array}{c}\mathrm{T} \\
(\mathrm{min})\end{array}$} & \multirow{2}{*}{$\begin{array}{c}\mathrm{V} \\
(\mathrm{V})\end{array}$} & \multirow{2}{*}{$\begin{array}{c}\mathrm{f} \\
(\mathrm{Hz})\end{array}$} & \multicolumn{3}{|c|}{ PW (ms) } \\
\hline & & & & 2 & 3 & 4 \\
\hline $\mathrm{C} 37$ & 15 & 100 & 1 & $3.62 \mathrm{a}$ & $5.87 \mathrm{a}$ & $6.00 \mathrm{a}$ \\
\hline $\mathrm{C} 38$ & 15 & 100 & 5 & $6.25 \mathrm{a}$ & $5.37 \mathrm{a}$ & $5.37 \mathrm{a}$ \\
\hline C39 & 15 & 200 & 1 & $3.62 \mathrm{a}$ & $5.50 \mathrm{a}$ & $7.00 \mathrm{a}$ \\
\hline $\mathrm{C} 40$ & 15 & 200 & 5 & $5.50 \mathrm{a}$ & $3.50 \mathrm{a}$ & $3.00 \mathrm{a}$ \\
\hline C41 & 30 & 100 & 1 & $8.25 \mathrm{a}$ & $7.12 \mathrm{a}$ & $4.87 \mathrm{a}$ \\
\hline $\mathrm{C} 42$ & 30 & 100 & 5 & $5.87 \mathrm{a}$ & $7.87 \mathrm{a}$ & $5.87 \mathrm{a}$ \\
\hline $\mathrm{C} 43$ & 30 & 200 & 1 & $7.37 \mathrm{a}$ & $9.25 \mathrm{a}$ & $7.62 \mathrm{a}$ \\
\hline $\mathrm{C} 44$ & 30 & 200 & 5 & $1.50 \mathrm{a}$ & $-0.12 a$ & $1.12 \mathrm{a}$ \\
\hline
\end{tabular}

Note: The averages followed by the same letter in the lines did not differ at $5 \%$ probability by the $\mathrm{F}$ test. 
Table 7. Survival rates for the species Eisenia foetida after 5, 10 and 15 days of exposure to the electrical field

\begin{tabular}{|c|c|c|c|c|c|c|c|}
\hline \multirow{2}{*}{$\begin{array}{l}\text { PW } \\
(\mathrm{ms})\end{array}$} & \multirow{2}{*}{$\begin{array}{l}\mathrm{V} \\
(\mathrm{V})\end{array}$} & \multirow{2}{*}{$\begin{array}{c}\mathrm{T} \\
(\min )\end{array}$} & \multirow{2}{*}{$\begin{array}{c}\mathrm{f} \\
(\mathrm{Hz})\end{array}$} & \multirow{2}{*}{$\begin{array}{c}\text { MC } \\
\text { (\% w.b.) }\end{array}$} & \multicolumn{3}{|c|}{ Survival rate $(\% /$ day $)$} \\
\hline & & & & & 5 & 10 & 15 \\
\hline 2 & 100 & 15 & 1 & 65.59 & 100.00 & 100.00 & 100.00 \\
\hline 3 & 100 & 15 & 1 & 65.80 & 100.00 & 100.00 & 100.00 \\
\hline 4 & 100 & 15 & 1 & 65.44 & 100.00 & 100.00 & 100.00 \\
\hline 2 & 100 & 30 & 1 & 65.59 & 100.00 & 100.00 & 100.00 \\
\hline 3 & 100 & 30 & 1 & 65.80 & 100.00 & 100.00 & 100.00 \\
\hline 4 & 100 & 30 & 1 & 65.44 & 100.00 & 100.00 & 100.00 \\
\hline 2 & 100 & 15 & 5 & 61.70 & 100.00 & 100.00 & 100.00 \\
\hline 3 & 100 & 15 & 5 & 64.45 & 100.00 & 100.00 & 100.00 \\
\hline 4 & 100 & 15 & 5 & 68.26 & 100.00 & 100.00 & 100.00 \\
\hline 2 & 100 & 30 & 5 & 63.27 & 100.00 & 100.00 & 100.00 \\
\hline 3 & 100 & 30 & 5 & 64.45 & 100.00 & 100.00 & 100.00 \\
\hline 4 & 100 & 30 & 5 & 64.45 & 100.00 & 100.00 & 100.00 \\
\hline 2 & 200 & 15 & 1 & 65.70 & 100.00 & 100.00 & 100.00 \\
\hline 3 & 200 & 15 & 1 & 65.92 & 100.00 & 100.00 & 100.00 \\
\hline 4 & 200 & 15 & 1 & 65.63 & 100.00 & 100.00 & 100.00 \\
\hline 2 & 200 & 30 & 1 & 63.24 & 100.00 & 100.00 & 100.00 \\
\hline 3 & 200 & 30 & 1 & 63.24 & 100.00 & 100.00 & 100.00 \\
\hline 4 & 200 & 30 & 1 & 65.92 & 100.00 & 100.00 & 100.00 \\
\hline 2 & 200 & 15 & 5 & 65.61 & 92.50 & 92.50 & 92.50 \\
\hline 3 & 200 & 15 & 5 & 66.78 & 97.50 & 97.50 & 97.50 \\
\hline 4 & 200 & 15 & 5 & 65.51 & 95.00 & 95.00 & 95.00 \\
\hline 2 & 200 & 30 & 5 & 65.61 & 92.50 & 92.50 & 92.50 \\
\hline 3 & 200 & 30 & 5 & 66.76 & 92.50 & 92.50 & 92.50 \\
\hline
\end{tabular}

Note: MC is the moisture content of the substrate (humus) in percentage, wet basis.

\section{CONCLUSIONS}

- It was verified that the utilization of electrical signals is a technically viable method for the separation of Eisenia foetida earthworms from humus. Therefore, there is potential for application of this technology at the commercial scale, which induces displacement of the earthworms when submitted to controlled electrical signals, preferably in the direction of the anode. The results found in the present study are useful to build equipment for separating earthworms from substrate with minimized manpower while preventing injury to the animals. 
- The maximum displacement index obtained was 9.35 , occurring for the combination involving a voltage $(\mathrm{V})$ of $200 \mathrm{~V}$, pulse width (PW) of $3 \mathrm{~ms}$, frequency (f) of $1 \mathrm{~Hz}$, and exposure time $(\mathrm{T})$ of 30 minutes.

- The effect of exposing earthworms to electrical pulses on the mortality rate was near to zero after 15 days of testing.

\section{ACKNOWLEDGMENTS}

The authors would like to thank CNPq, CAPES, FAPEMIG and the Federal University of Viçosa for providing the opportunity and for the financial support to perform this study.

\section{REFERENCES}

ADI, A.J.; NOOR, Z.M. Waste recycling: Utilization of coffee grounds and kitchen waste in vermicomposting. Bioresource Technology, v.100, p.1027-1030, 2009.

ARANCON, N.Q.; EDWARDS, C.A.; BIERMAN, P. Influences of vermicomposts on field strawberries: Part 2. Effects on soil microbiological and chemical properties. Bioresource Technology, v.97, p.831-840, 2006.

ATIYEH, R.M.; LEE, S.; EDWARDS, C.A.; ARANCON, N.Q. ; METZGER J.D. The influence of humic acids derived from earthworm-processed organic wastes on plant growth. Bioresource Technology, v.84, p.7-14, 2002.

BLANCHART, E.; ALBRECHT, A.; BROWN, G.; DECAENS, T.; DUBOISSET, A.; LAVELLE, P.; MARIANI, L.; ROOSE, E. Effects of tropical endogeic earthworms on soil erosion.Agriculture, Ecosystems and Environment, v.104, p.303315, 2004.

BOUMA, J.; CURRY, J.P.; HOUBA, V.J.G. Measuring physical, chemical and biological soil parameters in grasslands. In: Field and laboratory methods for grassland and animal production research. Cabi Publishing, 1 ed, p.279-303, 2001.
CHAOUI, H.; KEENER, H.M. Separating earthworms from organic media using an electric field. Biosystems engineering, v.100, p.409-421, 2008.

COJA, T.; ZEHETNER, K.; BRUCKNER, A.; WATZINGER, A.; MEYER, E. Efficacy and side effects of five sampling methods for soil earthworms (Annelida, Lumbricidae). Ecotoxicology and Environmental Safety, v.71, p.552-565, 2008.

DOMINGUEZ, J.; EDWARDS, C.A.; ASHBY, J. The biology and population dynamics of Eudrilus eugeniae (Kingberg) (Oligochaeta) in cattle waste solids. Pedobiologia, v.45, p.341-353, 2001.

JOHNSON-MAYNARD, J.L.; UMIKER, K.J.; GUY, S.O. Earthworm dynamics and soil physical properties in the first three years of notill management.Soil \& Tillage Research, v.94, p.338-345, 2007.

MAZZONI, R.; FENERICH-VERANI, N.; CARAMASCHI, E.P. Electrofishing as a sampling technique for coastal stream fish populations and communities in the Southeast of Brazil. Revista Brasileira de Biologia. v.60, n.2, p.205-216, 2000.

NDEGWA, P.M.; THOMPSON, S.A. Integrating composting and vermicomposting in the treatment and bioconversion of biosolids. Bioresource Technology, v.76, p.107-112, 2001.

OLIVEIRAFILHO, D; FERRAZ, D. I.; MARTINS, J.H., SANTOS L.C.; RIBEIRO FILHO, O.P.; COSTA, D.R. Avaliação do deslocamento de minhocas (Eudrilus Eugeniae) submetidas a pulsos elétricos controlados. Revista Brasileira Engenharia Agrícola e Ambiental, v.9, n.3, p.433-440, 2001.

OLIVEIRA FILHO, D; FERRAZ I.D. MORAES, M.J. ;MARTINS, J.H. ; SANTOS, C.L. Evaluation of Induced Earthworms (Eudrilus Eugeniae and Eisenia Foetida) Movement under Controlled Electric Pulses. American Society of Agricultural Engineers, USA, v.1, n.1-16, p.145-165, 2004.

RUSHTON, S.P.; LUFF, M.L.A new electrical method for sampling earthworm populations, Pedobiologia, v.26, p.15-19, 1984. 
SINHA, R.K.; HERAT, S.; AGARWAL, S.; ASADI, R.; CARRETERO, E. Vermiculture and waste management: study of action of earthworms Elsenia foetida, Eudrilus engenice and Perionyx excavates on biodegradation of some community wastes in India and Australia. The Environmentalist, v.22, p.261-268, 2002.

STEFFEN, R.B., BENEDETTI, T.; ANTONIOLLI,
Z.I. Caracterização molecular de duas espécies de oligoquetas. Revista Brasileira de Agroecologia, v.1, n.1, p.573-576, 2006.

SUTHAR, S. Vermicomposting of vegetablemarket solid waste using Eiseniafoetida: Impact of bulking material on earthworm growth and decomposition rate. Ecological Engineering, v.35, p.914-920, 2009. 